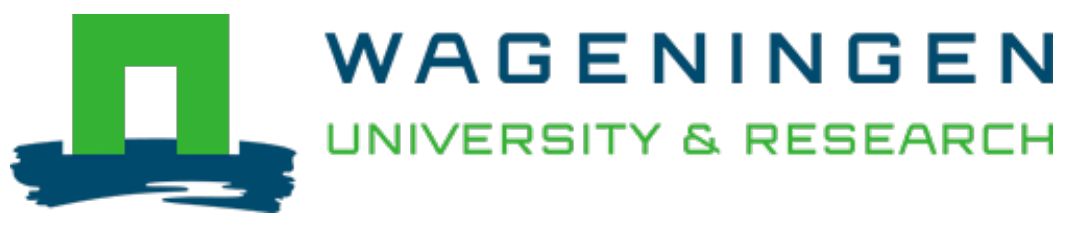

\title{
'Castle in the sky':The anomaly of the millennium villages project fixing food and markets in Sauri, western Kenya
}

Journal of Rural Studies

Kimanthi, Hellen; Hebinck, Paul

https://doi.org/10.1016/j.jrurstud.2017.12.019

This article is made publicly available in the institutional repository of Wageningen University and Research, under the terms of article $25 \mathrm{fa}$ of the Dutch Copyright Act, also known as the Amendment Taverne. This has been done with explicit consent by the author.

Article 25 fa states that the author of a short scientific work funded either wholly or partially by Dutch public funds is entitled to make that work publicly available for no consideration following a reasonable period of time after the work was first published, provided that clear reference is made to the source of the first publication of the work.

This publication is distributed under The Association of Universities in the Netherlands (VSNU) 'Article $25 \mathrm{fa}$ implementation' project. In this project research outputs of researchers employed by Dutch Universities that comply with the legal requirements of Article $25 \mathrm{fa}$ of the Dutch Copyright Act are distributed online and free of cost or other barriers in institutional repositories. Research outputs are distributed six months after their first online publication in the original published version and with proper attribution to the source of the original publication.

You are permitted to download and use the publication for personal purposes. All rights remain with the author(s) and / or copyright owner(s) of this work. Any use of the publication or parts of it other than authorised under article $25 \mathrm{fa}$ of the Dutch Copyright act is prohibited. Wageningen University \& Research and the author(s) of this publication shall not be held responsible or liable for any damages resulting from your (re)use of this publication.

For questions regarding the public availability of this article please contact openscience.library@,wur.nl 


\title{
'Castle in the sky': The anomaly of the millennium villages project fixing food and markets in Sauri, western Kenya
}

\author{
Hellen Kimanthi ${ }^{\mathrm{a}}$, Paul Hebinck ${ }^{\mathrm{a}, \mathrm{b}, *}$ \\ ${ }^{a}$ Department of Social Sciences, Sociology of Development and Change, Wageningen University, The Netherlands \\ ${ }^{\mathrm{b}}$ Faculty of Science and Agriculture, University of Fort Hare, Alice, South Africa
}

\begin{abstract}
A B S T R A C T
Millennium Villages Project (MVP) was implemented in various villages across sub-Saharan African countries to catalyse the achievement of the Millennium Development Goals (MDGs) and provide evidence of step-wise societal transformation by 2015. This paper critically analyses from an assemblage perspective the MVP's 'quick win' strategy to achieve the MDGs with a focus on the implementation of agricultural interventions and their impacts on the socio-technical fabric in Sauri Millennium Village (SMV) in western Kenya. Our anatomy of MVP highlights that MVP is a continuation of a decades-long of development approaches that sets out to fix development. Analysis of our qualitatively collected longitudinal data show that the SMV was blind to individual and collective forms of agency and heterogeneity among the social actors; hence grassroots corruption, elite capture of agricultural inputs, injury of social relations and exacerbation of the existing inequalities within the community. It spawned tensions and suspicions within the community. The farmers reworked the introduced ideas and technologies to fit to their needs and actively engaged with their own locally produced and exchanged resources. Typical for SMV was also an extremely questionable style of reporting that hid its achievements and failures from the general public. The "Big Promise" that MVP would deliver did not materialise; it simply failed to achieve its objectives and was unable to learn from previous interventionist strategies, it fractured communities and faded into oblivion.
\end{abstract}

\section{Introduction}

World development history is characterised by a succession of interventionist development strategies which have in common the intention to reduce poverty and create conditions for sustained economic growth by increasing institutional and technical efficiencies. The underlying discourses of planned development have remained largely unchanged over the years. This fortified continuities rather than generating robust discontinuities (Escobar, 2011: 21-54), while new development questions and challenges such as enduring poverty, malnutrition, child mortality, insecurity have emerged since then. Continuities at the level of development discourse to expand and deepen the processes of 'modernisation' (Arce and Long, 2000) through planned interventions are well present in the Millennium Village Project (MVP). Wilson $(2013,2015)$ perceives MVP likewise as a prime example of social engineering of a 'model village-style social experiment' and again as 'a living laboratory' whereby massive investments are made in integrated programmes at village level through planned interventions within a specific timeframe.

The MVP is a high-profile project implemented with substantial financial and ideological support from the United Nations, political celebrities, business elites and academia to accelerate achieving the Millennium Development Goals (MDGs). MVP was piloted in 2005 in two villages in sub-Saharan Africa and up-scaled to about ten in 2007 and since then to 80 villages. Over the years, these projects have been praised for achieving considerable progress in the fields of education, health and, notably, smallholder agriculture (Sanchez, 2006; Sanchez et al., 2007; Nziguheba et al., 2010; Denning et al., 2009; Deckelbaum et al., 2006; Pronyk et al., 2012). MVP and more generally the MDGs, however, have been subjected to critical evaluations (Easterly, 2009; Hulme, 2009, 2010.) MVP has specifically been critiqued for not disclosing project data for independent, objective analyses (Clemens and Demombynes, 2011, 2013) and not achieving impact despite massive funding (Wilson, 2013, 2015, 2016; Wanjala and Muradian, 2013; Carr, 2008; Clemens et al., 2007). Others have argued that the purpose of most development interventions is to further capitalism and entrepreneurial values in various ways (Umans and Arce, 2014: 342) and to extend processes of 'accumulation by dispossession' (Wilson, 2016; Harvey, 2009). This paper sets out from an assemblage perspective to contribute to a critical and reflexive analysis of the MVP and to explore,

\footnotetext{
* Corresponding author

E-mail address: paul.hebinck@wur.nl (P. Hebinck).
} 
for instance, why, and how, despite that the outcomes and impact of MVP are questionable, it managed to legitimize continuous external funding to carry out its activities.

Building on the body of literature on assemblage and (re)assembling processes, we pursue here this analytic to explore the dynamics generated by the MVP and more specifically the SMV. We unravel MVP as an assemblage of people, discourses, technologies and other material elements; these are brought together to address societal problems and needs. This allows us conceptualising MVP as an assemblage that attempts to transform existing assemblages; an assemblage that claims to help create assemblages that strengthen and improve rural livelihoods and reduce poverty in this way. MVP can also be branded as an assemblage that sets out to fix solutions for problems through planned development (Umans and Arce, 2014) or through what Li (2007a, 2007b) has qualified as 'rendering technical'. Solution fix and rendering technical are among the practices that Li (2007a: 263) has classified as 'generic to any assemblage' and they are analysed as such. These practices express rather similar processes and are therefore used interchangeably here. Typical for such practices is that the style is interventionist, rather linear and bound by time and space.

Sauri Millennium Village (SMV) serves as an extended case. Sauri is the site were MVP was first piloted in Africa. SMV is important for the upscaling of MVP to other countries and would generate viable lessons for the international development community. We decided to focus our analysis on the agricultural interventions taking place in SMV. The primary objective on balance was to eliminate hunger, although 'improving agriculture in itself is unlikely to get rural communities in sub-Saharan Africa out of poverty' (Nziguheba et al., 2010: 111; Sachs, 2005; Sanchez, 2006). Sauri also offers the opportunity to draw on unique longitudinal data from a series of ongoing field studies in the region in which Sauri is situated from 1996 up to the present, that is, well before SMV was designed and implemented. These studies depict what generally characterises Sauri's assemblage before SMV was launched in 2005. They underscore that the people in Sauri noticeably share a history of distancing from the products of previous interventionist strategies. They have a strong tendency to continue to trust and rely on their own resources, whose use is embedded in locally shared and accepted cultural norms, and to reproduce what they can and share among themselves. This is not necessarily out of poverty which in the MVP and MDG conceptualisation of development is the condition whereby people lack the capital means to purchase the newest agricultural inputs and to engage with mainstream markets. They do engage with markets that they construct themselves and tend to enrich the key human and non-human resources themselves (Hebinck et al., 2015; Kimanthi, 2014; Mango and Hebinck, 2004; Mango, 2002; van Kessel, 1998).

Our longitudinal data and interpretations thereof permit us to pinpoint which processes at play explain why MVPs, and SMV in particular, fail to turn farmers into entrepreneurs attaining surplus yields for the market by making use of proven inputs made accessible through formal organisations such as the cooperatives. We elaborate on how SMV became vulnerable to an elite capture of inputs, injured social relations, exacerbated the existing inequalities and thus fractured the community. We also show how the SMV's approach to fixing food [production] in Sauri was concomitant with the ambition to show success - a 'twisted' way of fixing solutions, resulting in questionable data reporting.

The paper proceeds as follows: we first explain the conception of MVP and its implementation in countries in sub-Saharan Africa. The next sections discuss our ways of data collection and shortly elaborate our methodology for analysis by explaining what we mean by assemblage and why MVPs and SMV can be conceptually unpacked as assemblage. What then follows is an analysis of how, and in what ways, SMV tried to assemble and display project success. The last section discusses against the background of the broader literature the specificities of MVP inspired assemblages. We particularly pay attention to farmers' (re)assembling practices in response to SMV practices. In our concluding section, we reiterate the significance of our analysis for the study of agrarian development and promote, argue for and suggest more robust interventions that strengthen assemblages in which farmers, villages, communities are not the object of external interventions. Such assemblages potentially appreciate fully the capabilities of human and non-human actors within the villages as they do not relate to the villages as external actors.

\section{The birth and implementation of MVP in African countries}

The 1970's saw the emergence of the Integrated Rural Development (IRD) approach to planning and development (ODI, 1979; Ellis and Biggs, 2001) which was soon followed in the 1990's by Structural Adjustment Policies (SAPs) (Stiglitz, 1998). IRD was a response to failures of previous technocratically conceived strategies like the Green Revolution whose impact was limited to those regions that are endowed with conducive natural and social conditions (Griffin, 1979; Pearse, 1980, 1977). IRD stood for widening the scope of development interventions beyond agriculture per se to include other economic sectors like education, health and physical infrastructure (ODI, 1979; Ellis and Biggs, 2001). It also called for proper (state) planning and participation of the less fortunate through mobilisation, income and assets redistribution and an increase in technical and institutional efficiencies in order to raise marketable production. All these served to ease the integration of subsistence farmers into the market economy to reduce poverty and in turn to enhance participation (Leupolt, 1977; Ellis and Biggs, 2001; Ashley and Maxwell, 2002).

SAPs, on the other hand, called for a retreat of the state as the donor community lost confidence in central planning and the key political and economic role of the state in the economy. State control would hinge too much on economic inefficiencies, restrictions, patronage and political prices rather than real prices. Trade-liberalisation, more space for the market and private property arrangements and entrepreneurship would trigger development. Stiglitz (1998) critiqued SAPs as being inadequate for not considering the 'underlying factors' of social life in the rural areas which prevented rural households from participating in the market. He showed that the need arises for a paradigm based on a broad conception of development that would allow for a broad and inclusive vision of development strategies, one that would assign international development assistance a different position and role which included a different way of delivery to the people. In short, the earlier development paradigms viewed development too narrowly and thus did not succeed (Stiglitz, 1998: 1-2). SAPs were succeeded by the international prestige project MDGs (Hulme, 2009; Sachs, 2005; Sachs and McArthur, 2005; DFID, 2002).

The MDGs were launched in 2000 by the world development leaders at the Millennium Summit as the next global development strategy that would make a difference. Initially, eight goals were formulated which would lead to the transformation of societies, reduce poverty and improve the standards of living across the globe by 2015 (Sanchez, 2006; Sanchez et al., 2007; Sachs, 2005). The MDGs were designated as 'the world's biggest promise' and deemed too important to fail (Wilson, 2013:2; Hulme, 2010:15). However, it was realised after some time that most countries in the Global South were not likely to achieve these goals by the year 2015. The then UN Secretary-General Kofi Annan commissioned the Millennium Project to formulate a strategy for the achievement of MDGs which were then implemented as Millennium Villages. MVP was born out of the perceived need to catalyse the achievement of the MDGs. Headed by Jeffrey Sachs ${ }^{1}$ and assisted by former director of ICRAF, Pedro Sanchez, and associates from Earth University, MVP formed a 'task force' that included representatives of the World Bank, the IMF, UN and donor agencies, civil society

\footnotetext{
${ }^{\mathbf{1}}$ Wilson (2014) devoted an entire book to Jeffrey Sachs clearly illuminating how Sachs' career has evolved and why neoliberalism entices him.
} 
organisations, the private sector and celebrities like Bono and Bill Gates (Binagwaho and Sachs, 2005; Carr, 2008; Sanchez et al., 2007; Hulme, 2009; Kanter et al., 2009). The Earth Institute from the University of Columbia in the USA, played a key role in design of MVP. In Sachs's words:

'All of the UN Millennium Project work has depended utterly on the Earth Institute. Fundamentally, progress on the MDGs rests on thorough scientific understanding of the underlying challenges of disease, food production, undernutrition, watershed management, and other related issues. These, in turn, require specialized expertise. Modern science has given us technological interventions, or specific techniques for addressing these problems, such as antimalarial bed nets or antiretroviral drugs' (Sachs, 2005: 224).

Wilson (2016:4) refers to the projects emanating from such configurations in which philanthropists play a central role as examples of 'philanthrocapitalism'. 'Unlike previous forms of charity and philanthropy, philanthrocapitalism claims to infuse its projects with the dynamism and innovation of capitalist enterprise'. Hence the strong focus on establishing and nurturing entrepreneurship and achieving measurable success. Development projects should moreover be based on scientific insights, goal-driven, realize quantifiable outputs and have a strategy in place to scale-up interventions to national and regional levels (Sachs, 2005; Sanchez, 2006; Kanter et al., 2009; Wilson, 2013, 2016). It was also clearly felt that the MDGs were either not met or hardly met and certainly not fast enough achieved. MDGs made progress but more could be achieved provided they were properly targeted (Sachs and McArthur, 2005). The MVP model stipulates that poverty and hunger can only be reduced by accelerating the transformation of the resource base of the societies and their economies in the Global South from reliance on the 'traditional' to adoption of the 'modern'. This model would deliver and help articulate assemblages where all other previous approaches to development failed to do so (Sanchez, 2006; Sachs, 2005; Cabral et al., 2006; Sanchez et al., 2007; Kanter et al., 2009).

MVP was thus launched, legitimised and positioned as an assemblage for empowering communities to invest in a package of integrated interventions that aim to increase food production, improve access to safe water, health care, education, and develop infrastructure. The process benefits from synergies of the integrated approach and relies on community leadership being empowered by scientifically proven technological inputs such as hybrid maize. MVPs were first implemented in sub-Saharan Africa from 2005 onwards, gradually expanding and upscaling from 2 villages - Sauri in Kenya and Koraro in Ethiopia - to ten additional villages in Ghana, Kenya, Malawi, Mali, Nigeria, Rwanda, Senegal, Tanzania, and Uganda (Sanchez, 2006; Cabral et al., 2006). At a later stage MVP's were carried out in 80 sub-Saharan villages (Kanter et al., 2009).

The key MVP interventions of the agricultural sector were to deliver and introduce the agricultural inputs that would increase production and resonate with the prevailing agro-ecological conditions. The villages where MVPs were implemented are said to have been carefully selected to represent each of the twelve principal agro-ecological zones and farming systems in Africa (Mutuo et al., 2007: 7; Sanchez et al., 2007). The MVP builds clearly on the Green Revolution strategy that set out to transform the agricultural sector through the introduction of a modern, scientifically proven agricultural technology package consisting of improved crop germplasm adapted to local conditions ${ }^{2}$ and fertilizer application combined with field-based extension (Nziguheba et al., 2010: 111). Additionally, MVP introduced 'formal' market organisations through which farmers would acquire inputs and sell their produce. It was thought that if organised into producers' groups, farmers could negotiate higher prices and linkages to buyers

\footnotetext{
${ }^{2}$ This may be the formal position; in practice in Sauri it was hybrid maize seed that was provided (often on credit).
}

(Nziguheba et al., 2010: 111). Sanchez (2006:3) spells out that to achieve success via this approach requires careful sequencing of interventions; a typical infusion of the classic Rostovian Stages of Growth perspective. He framed it as

'getting out of the hunger/disease trap first is essential before one can move on to sell crop surpluses, enter the market' and transform the economy. It was thought that for MVP to succeed, it would be essential to 'fix the market infrastructure and combat trade and food aid distortion'.

Those that contributed to the MVP-strategy simply assumed, as Hobart and many of his contemporaries argued, that

'a green-revolution-style breakthrough in smallholder farm productivity is central to escape the poverty trap throughout rural Africa and that an African Green Revolution is crucial for dual purposes; to tackle hunger and to kick-start rural economic growth by raising productivity and rural incomes' (Hobart, 1993:10). ${ }^{3}$

\section{Methodology and data collection}

The setting of this paper is the Sauri sub-location which is situated in the Yala division of Siaya County in western Kenya (Figs. 1 and 2). As of 2004, Sauri became known to the outside world as the first Millennium Village. The specific focus of this paper on Sauri also lies in a number of important and additional reasons:

Firstly, the emphasis on Sauri allows us to draw on findings from a series of ongoing longitudinal studies initiated in 1996 in Nyamninia, Muhanda, Muhoho and Sauri villages in the Yala division (van Kessel, 1998; Mango, 1996, 1999, 2002; Mango and Hebinck, 2004, 2016; Hebinck, 2001; Hebinck and Mango, 2008 and Hebinck et al., 2015). The objective of these studies was to analyse and consider the dynamics generated over a longer period of time by a range of socio-technical interventions such as the Green Revolution, Agro-forestry and ZeroGrazing, what impacts these had on rural livelihoods and the social fabric in the villages, but also how these interventions were contested, re-assembled and negotiated at the household and field level to resonate with local conditions and shared preferences. Multiple qualitative methods of data collection were used, which included document and archival reviews, life history interviews, key informant interviews and interviews with farmers, ethnographic observations and case studies through revisits of the previously recorded cases. ${ }^{4}$

Secondly, Sauri is situated in western Kenya, a region that has been subject to a range of interventions programmed, funded and implemented by the Colonial state as well as by the Kenya Government in collaboration with international donors and agencies after Independence in 1963. The region and past and present interventions have been thoroughly studied and documented (Oguto, 1971; Hay, 1972; Heyer, 1975; Obhudo and Waller, 1976; Kitching, 1980; Carlsen, 1980; Cohen and Odiambo, 1989; Shipton, 1995; Crowley, 2000). These studies that also informed our longitudinal studies provide a historical and contemporary account of the processes of agrarian transformation. Despite being implemented in different historical and political circumstances, the intervention programmes all advocate for the transformation from 'subsistence' to 'commercial' agriculture.

Thirdly, the implementation of MVP in Sauri attracted independent researchers who wrote up their findings in unpublished Masters and

\footnotetext{
${ }^{3}$ The Green Revolution is much debated among experts, academics, development agencies and lobby groups. It goes beyond the scope of this paper to extensively discuss whether or not the Green Revolution was successful in increasing the productivities of land and labour in Africa or whether it is relevant to speak of a 'First' or 'Second' or even a 'New' Green Revolution.

${ }^{4}$ The value of revisits and restudies is widely acknowledged in social science studies, notably in anthropology and rural development sociology (Geertz, 1995; Long, 2001; Burawoy, 2003; Li, 2014).
} 


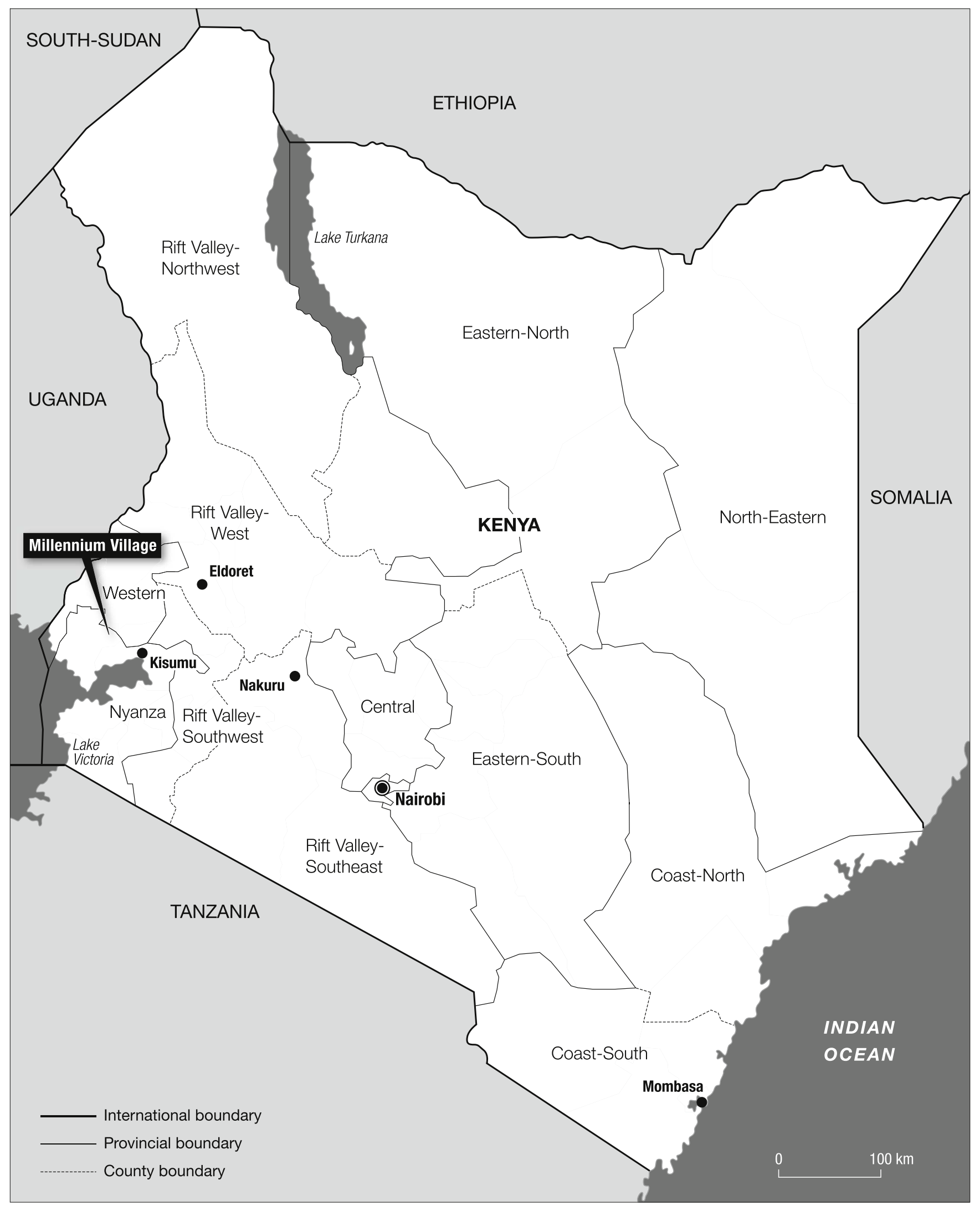

Fig. 1. Kenya and the location of Yala.

Ph.D. theses (Haro, 2014; Wanjala, 2016; Yuksel, 2013) and journal articles (Wanjala and Muradian, 2013). The objective of their studies was, like ours, to examine the MVP project from a critical, reflexive perspective. Whereas Wanjala (2016) was largely quantitative, Haro
(2014) and our studies were largely qualitative. While their studies were time bound, our studies span a longer time frame. This allows for an ex-ante analysis and a strong focus on agricultural technology and processes of transformation and ex-post. Together these studies 


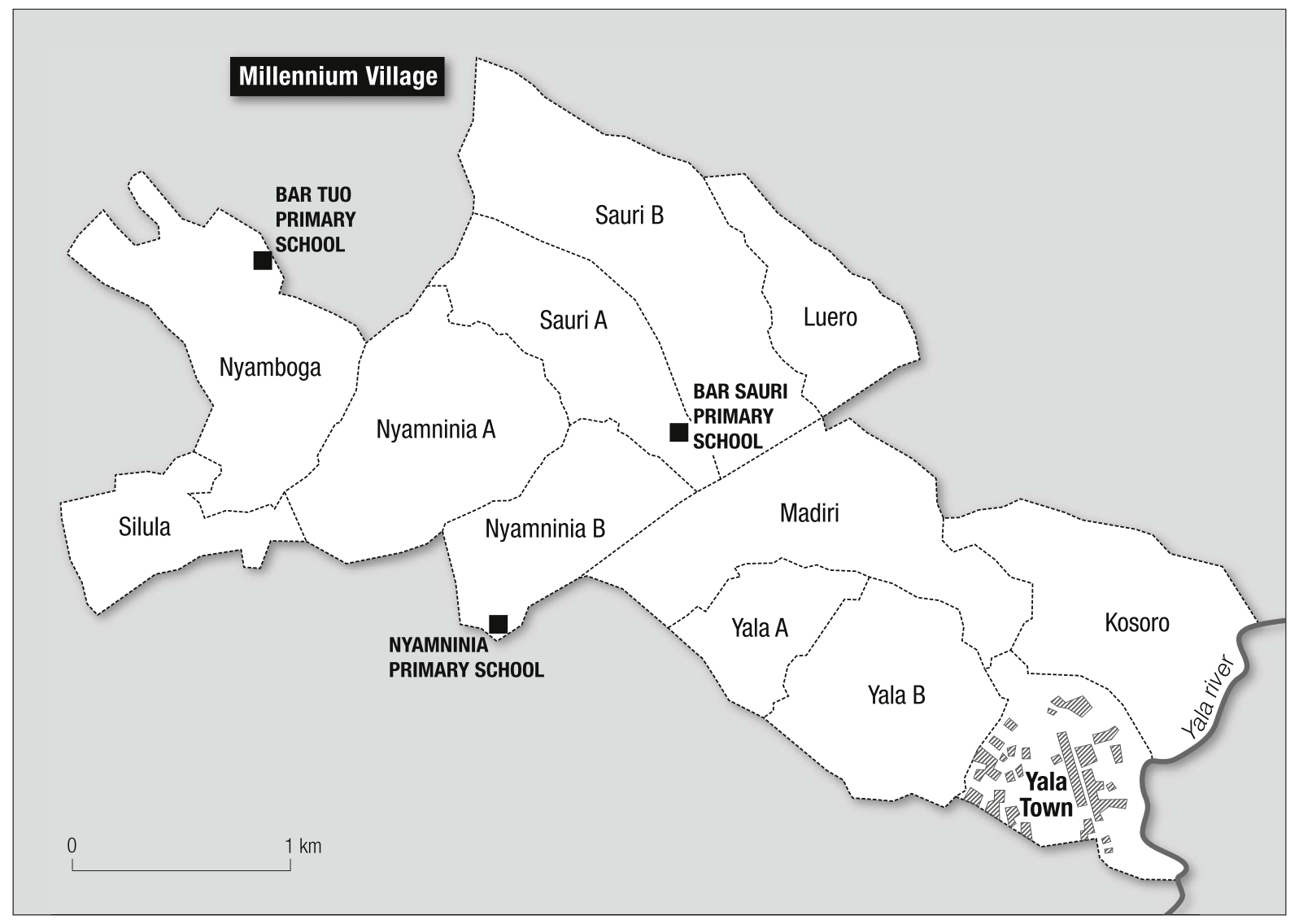

Fig. 2. Sauri Millennium Village, a conglomerate of 11 villages.

Source: Adapted from (Mutuo et al. (2006): 6).

delivered significant data, observations and in-depth insights into SMV.

This paper specifically makes use of a two-month intense period of data collection in Sauri that was done for a master thesis (Kimanthi, 2014). It traced the impact of SMV on current maize and land use practices and extracted detailed accounts of how farmers experienced the implementation of SMV 'from below'. New field studies are currently being carried out at the time of writing this paper. Field studies were combined with a desk study and a document review of MVP reports that became available to us during the course of fieldwork. The household and field levels formed the targets of the MVP interventions, and these are the levels where important processes of interactions with introduced technologies took place. A total of 21 people were 'formally' interviewed in depth in 2014, 5 of whom were key informants and 16 of whom were farmers. Four farmers were part of previous studies (notably van Kessel, 1998; Mango, 2002). The other informants were selected randomly, purposively and through snowballing. They included those farmers who engaged actively with MVP activities, those who had withdrawn from or distanced themselves from using the introduced technologies and market channels, the members of newly formed grassroots initiatives, adopters and those who partly applied the recommended technologies. The key informants were purposively selected due to their knowledge of the MVP operations in Sauri as well as their interactions with the farmers. In addition to the 'formal' interviews, other respondents provided information that served as a confirmation or rather a data back-up of the 'formal' interviews. These respondents were ethnographically interviewed during the daily interactions with the people and participated in some of the village-level group meetings. Ethnographic observations were made as well.

The 2014-restudy enabled us to compare our data and findings with the available data published in MVP reports and the recent studies by Wanjala (2016) and Haro (2014). It is important to note in advance that our efforts to access data through the official MVP channels from the field and regional offices in Sauri and Kisumu respectively bore no fruit and also that the MVP staff were not allowed to be interviewed by independent researchers who were not vetted by the leaders. However, our ethnographic explorations in Sauri and our prior knowledge of the village and region compensated for that. We also managed to access some confidential reports from SMV field staff and informal interviews with the field staff.

An essential component of our methodology is the longitudinal studies, published in books papers, Master and Ph.D. theses and research and project reports, which enabled us to position SMV in a proper historical setting of the region and its people. The studies simultaneously furnished the key building blocks for an in-depth ex-ante and ex-post situational account and analysis of the dynamics generated by MVP. These studies clearly showed that neither past nor present development interventions to transform the socio-technical fabric endured; nor were these well received and accommodated by people in the villages. Our ex-ante studies (Hebinck and Mango, 2008; Hebinck et al., 2015; Mango, 1996, 1999, 2002; Mango and Hebinck, 2004) which show in detail the dynamics in agriculture within the area prior to MVP implementation give us the added advantage of comparing the ex-post and ex-ante situations.

\section{MVP as assemblage}

Based on the reading of the original work of Deleuze and Guattari (1987) by Li (2007a), McFarlane (2009), McFarlane and Anderson (2011) and Woods (2015) we conceptualise assemblages as being made up of heterogeneous elements with varied properties that constantly interact with each other; they are continuously transforming and reproducing. Assemblages are the locally specific outcome of the 
interaction and mutual shaping of socio-cultural, institutional and nonhuman elements; these elements are continually rearranged though processes of reassembling to form new connections and relationships that may not have existed previously. Assemblages are dynamic and constantly changing. Assembling 'can only ever be a provisional process: relations may change, new elements may enter, alliances may be broken, new conjunctions may be fostered' (McFarlane and Anderson, 2011: 126). The SMV analysed here in detail is testimony of that dynamism.

Viewing MVP as assemblage reconceptualises planned interventions as attempts to transform existing assemblages into new ones that promise to be internally more coherent, more productive and that strengthen existing livelihoods. The MVP assemblage consists of drawing and (re)assembling disparate elements together through various practices that are aimed at improvement (or believed to do so) by implementing various interventions for treatment of the diagnosed deficiencies such as hunger from low production (Li, 2007a: 264). A clear objective of MVP was to drastically transform the 'sub-subsistence $^{5}$ farmers' to a single 'small-scale entrepreneurial community' (Sanchez et al., 2009: 40; Sanchez, 2006; Nziguheba et al., 2010). Expert advice and extension services were geared towards helping farmers to produce a surplus so as to venture into markets. MVP relied heavily on technical assistance to the farmers such as providing commoditised technology packages and strengthening marketing relations. Such advice, knowledge, and institutions were positioned as superior to locally embedded knowledge and repertoires of social organisation and exchange. There was very little attention, if any, paid to, for instance, the existing local knowledges and cultures of seeds, the way local resources are enriched and exchanged, and the social relations in which maize production and consumption is embedded (Mango, 2002; Mango and Hebinck, 2004; Hebinck et al., 2015). Ignoring by not taking into consideration the prevailing conditions, history, prior interventions, individual and collective agency and generally the complexity of social situations is typical for MVP-inspired assemblages such as SMV. Not surprisingly, the implementation of concrete activities was met with suspicion at the 'local' level of village and community. Thus what MVP assemblage aims to articulate is also subjected to negotiation and reassembling, eventually altering the intended outcomes (see also Olivier de Sardan, 2006; Long, 2001, 1977) and ultimately the assemblage itself. A focus on assemblage and particularly on the reassembling practices shows the subtleties of the agency of the social actors involved, be they experts or 'local people'. This in turn points to the limits of grand designs for development.

Li (2007a: $264 \mathrm{ff}$.) advances an analysis of assemblages through six practices that are generic to any assemblage: 1) forging alignments or networks; 2) rendering technical or solution-fix; 3) authorizing knowledge; 4) managing failures; 5) anti-politics, and 6) reassembling. Applying such an assemblage analytic helps displaying the dynamic and changing nature of the SMV assemblage, its inherent problems and the contradictions it generates. An assemblage perspective clearly adds to the critical literature on MVP and to the more broader literature on planned interventions. It points at the subtleties of labelling regions, villages and people as 'underdeveloped' and the ideology to further capitalism and entrepreneurial values in various ways (Umans and Arce, 2014: 342). But it also helps us show that MVP is more than just being captured by neoliberalism and extending processes of 'accumulation by dispossession' (cf. Harvey, 2005, 2009) as Wilson (2016) frames MVP. The reassembling that is going on by SMV-staff but more importantly by quite a number of farmers in Sauri is testimony of that. They continue to rely on and enrich their seed practices based on selecting and planting local maize seed instead of the modern varieties that SMV introduced (Hebinck et al., 2015). An assemblage perspective allows us to demonstrate how MVP brings together numerous social

\footnotetext{
${ }^{5}$ The notion sub-subsistence is a term taken from the MVP vocabulary. It is needless to say that we find this an extremely problematic concept.
}

actors (i.e. villagers, donors, experts, academics, project staff and traders), a range of objectives (poverty alleviation, sustainability, social transformation) and non-human actors (i.e. hybrid maize varieties, soils fertility technologies, cooperatives, new institutional arrangements) and how these interact. The interests and objectives of the social actors involved in SMV compose a dynamic but often conflictive mix. It allows us to analyse the problems inherent to 'solution-fix' practices to solving problems by making the implicit assumptions more explicit and transparent. The role played by experts emerges as crucial in and for the assemblage; similarly the need to forge alignments between human and non-human actors to maintain the assemblage and to liaise with donors and dealing with the outside world by assembling success with the purpose to sustain the assemblage. MVP also requires global celebrities and specifically poor villages and poor people. The latter are crucially important as their problems and deficiencies need to be solved in turn legitimizing the existence and reproduction of the assemblage. In the words of Jeffrey Sachs while visiting Sauri for the first time in 2004, SMV was designed to:

'(...) work(ing) with villagers to identify ways to help such communities to achieve the worldwide Millennium Development Goals of reducing extreme poverty, hunger, disease, and lack of access to safe water and sanitation' (Sachs, 2005: 228).

The MVP assemblage pivots on substituting the 'traditional' with the 'modern' or on inserting new and modern elements into existing assemblages. Characteristically, MVP creates space for interventions through the specific way communities and their resources are labelled and framed (Li, 2007a; Long, 2001; Umans and Arce, 2014). When people are labelled as 'poor' and their 'deficiency' identified as a lack of human, financial and physical capital, this reinforces and institutionalises tags such as 'poor farmers', 'impoverished people', 'inefficient traditional methods of farming', 'poor marketing strategies', 'low productivity' and so on. Yet they are seen by others as resourceful. During his first visit to Sauri for example, Sachs frames Sauri as follows:

'The visit made vivid both why extreme poverty persists in rural areas and how it can be ended. We found a region beset by hunger, AIDS, and malaria. The situation is far grimmer than is described in official documents. The situation is also salvageable, but the international community requires a much better understanding of its severity, dynamics, and solutions if the crisis in Sauri and the rest of rural Africa is to be solved. The situation is best understood through the voices of Sauri's struggling residents. In response to an invitation from our group, more than two hundred members of the community came to meet with us one afternoon. Hungry, thin, and ill, they stayed for three and a half hours, speaking with dignity, eloquence, and clarity about their predicament. They are impoverished, but they are capable and resourceful. Though struggling to survive at present, they are not dispirited but determined to improve their situation. They know well how they could get back to high ground' (Sachs, 2005: 227,228).

These are problematic labels and framings that are commonly applied and uncritically reproduced in reports by experts including those written by academics. Moreover, the data to sustain these framings and interpretations is derived from applying rather standardized assessments of the nature and robustness of the available human and non-human resources. These assessments are backed by engineering and natural sciences procedures which tend to interpret facts as given and objective rather than as constructed and negotiated. As a consequence, locally available resources that are found relevant by local people (e.g. their seeds, knowledge, experiences, culture, their interpretation of yield and nutrition) are overlooked and consequently labelled by experts as 'unproductive' and only rendering 'poverty'. Such labelling legitimises interventions that stress that the promises of development can only be fulfilled by introducing modern devices and procedures, new technologies, institutions, rules and regulations, and modern management systems. 
Experts (e.g. scientists, engineers, agronomists) play a key role in the everyday practice of the MVP assemblage: they help to design interventions and innovations and represent authorizing knowledge. Experts, moreover, combine claims to knowledge with a set of practices by which the development of the (agricultural) sector is directed; one in which problems are identified and solutions forged, proposed and implemented. Experts frame problems in terms amenable to technical solutions. These solutions fix the future as they typically have a forward-looking aspect, as (van der Ploeg (2003): 229) describes in his analysis of Dutch agricultural expertise: it does not concern so much "agriculture as it is now, let alone (recent) agricultural history. The expertise involves agriculture as it is expected to look in the future.". This provides experts potentially with the power to create "the rules that define and authorize participants" (van der Ploeg, 2003: 22), and that distinguishes them from those who impede the assemblage.

Li (2007a, 2007b) captures this repertoire of thinking and assessment with the notion 'rendering technical'. This is rather similar to what Umans and Arce (2014) characterise as 'solution-fix'. It understands framing problems as confined, knowable and controllable, implying in turn perceiving problems of development as solvable, but only once the right experts are called upon and their insights translated into action (Scott, 1998; see also Herbert-Cheshire and Higgins, 2004). The fixing of solutions simultaneously involves rendering non-political; that is, the solutions that are pre-determined to solve the problem are perceived as non-contested. Moreover, the community or village for which the interventions are designed and targeted is conceptualised as homogenous (see Carr, 2008 on this misconception, an issue we will come back to later) and as representing an average practice and experience, even though the community or village is made up of heterogeneous groups and individuals with diverse interests, goals, knowledge, desires, and education. Nevertheless, African villages are misconceived as homogenous entities.

However, as we will show in this paper, the assemblage that MVP desired to create did not materialise. Some of the local people responded to MVP interventions by retracting to their informal groups and informal market organisations as opposed to submitting to the introduced farmer cooperatives and cereal banking techniques. Furthermore, as MVP introduced technologies such as the newest hybrid maize seeds to the community to replace the preferred and trusted 'local' maize varieties (van Kessel, 1998; Mango, 2002; Hebinck et al., 2015), it interfered with the way farmers organised themselves around food cultivation and potentially destabilising the existing assemblages. We show in this article that despite the intended stabilising effect of MVP, the farmers continue to organise themselves in ways that have always worked for them such as production based on localised cultural repertoires and institutions as well as on a strong belief in the locally available resources such as local maize varieties and soil fertility replenishment practices (Hebinck et al., 2015; Mango and Hebinck, 2016). In our opinion, it is not poverty per se that motivates people in Sauri to continue to develop and enrich their resources such as the use of local maize varieties extensively and to draw from their own knowledge.

The MVP model is in stark contrast to making or rather facilitating local actors to be subject of their own development that Umans and Arce (2014) depict as 'fit-in-context' (see also Chambers, 1997; Hyden, 1983). Such an approach to development implies fitting in a solution to a complex situation rather than moulding the local realities to fit into the set objectives that are formulated by non-local actors. Development or progress in this line of thinking is constituted by assemblages some of which unfold as promising but robust, and internally coherent and consistent.

\section{Assembling success: analysis of Sauri millennium village project}

This section critically elaborates on SMV strategies to demonstrate that success can be achieved within a short time. The focus in this section is on the practices of the SMV assemblage elaborated earlier as generic to assemblages. We will elaborate these practices by offering a closer look at SMV reveals 1) forging alignments through a compromised choice of project location and enticing farmers with free gifts and promises 2) rendering technical and authorizing knowledge practices which is depicted in our analysis of the agricultural interventions and 3) management of failure which is treated by an analysis of the SMV's data secrecy as well as controversial reporting on the project. The reassembling aspect is dealt with in the next section. The depoliticizing elements of assemblages are recapped in the concluding section.

\subsection{The choice of Sauri for MVP implementation}

Sauri Millennium Village is made up of 11 smaller villages all of which are densely populated. It is an area with high potential for agriculture as it has a bimodal rainfall pattern that allows for a long and a short planting season a year. Water is readily available as there are natural springs across the villages in addition to the Yala river all of which never dries up (Mutuo et al., 2007). Nonetheless, Sauri is one of the areas that have been receiving financial assistance from international organisations for more than two decades now. ICRAF began research in the sub-location in the early 1990s in partnership with the Kenya Agricultural Research Institute (KARI) and Kenya Forestry Institute (KEFRI). Africa Now, which is a UK based charity organisation, worked with the communities in the late 1990s to support the building of spring-protection cisterns. CARE-Kenya and Heifer International also worked in the 1990s while the MVP started operating in 2004. Schlesinger (2007) argued that Sauri should not have been such an ideal choice for a site where 'an experiment' that aimed at poverty alleviation of the 'poorest of the poor' was to be carried out given that the development interventions had been ongoing on in the same area. She wondered: 'if one were truly attempting to establish a representative baseline of data for the MVP model, would it not be more logical to choose an untouched locale?' (Schlesinger, 2007: 2). ${ }^{6}$ However, it is claimed that Sauri was selected on the basis of poverty and hunger incidence in the area (Sachs, 2005; Pronyk et al., 2012:149; Wanjala and Muradian, 2013); Wanjala (2016) noted, however, that in 2014, Siaya county was ranked at that time as 10 th out of 47 counties in terms of poverty which means that there were several other poorer counties than Siaya county (Wanjala, 2016:8).

This triggers a probing question: how did MVP land in Sauri? A wellinformed respondent in Sauri explained that when ICRAF started research in Sauri in the early 1990s on soil fertility as part of ongoing research in western Kenya at that time, there were key personalities involved with the community. He told how the research was led by Dr. Niang Amadou, a Senegalese Principal Forester who was charged with the responsibility of developing methods for speeding up the adoption of agro-forestry innovations (see also Place et al., 2007a). He brought the idea of improved fallow technology to Luero village, one of the 11 villages in Sauri sub-location (Fig. 2) (Mango, 2002). In 1997, according to our informant, Dr. Amadou's boss, Professor Pedro Sanchez got personally involved in the agro-forestry research activities that were ongoing in the area.

Professor Pedro Sanchez was the director general of ICRAF at that time (1991-2001) and later on became the director of the MVP between 2004 and 2010. He was also the co-chair of the United Nations Millennium Village Project Hunger Task Force from 2002 to 2005 (Earth-Institute, n.d). ${ }^{7}$ Our key-informant explained that Professor Sanchez worked with them for about three years but before he left ICRAF he promised the farmers that he would come back with more

\footnotetext{
${ }^{6}$ Victoria Schlesinger is a writer, reporter, and editor who published a story about Sauri Millennium Village Project in 2007 in Harper's Magazine (http://www.vschlesinger. com/2013/06/23/harpers-magazine-the-continuation-of-poverty-the-rebranding-offoreign-aid-in-kenya/).

7 This information is available on the website of the Agriculture and Food Security Centre of Earth Institute, Columbia University: http://agriculture.columbia.edu/.
} 
development interventions. The local people organised a farewell party for him where he was crowned the Chief and named Odera Akang'o, after a famous chief who ruled during the colonial period. In 2004 Professor Sanchez returned with Professor Jeffrey Sachs, his colleagues from Earth Institute as well as a delegation of donors from the private sector and non-profit organisations to launch the MVP in Sauri. The people we interviewed in 2014 still had vivid memories of that event of 10 years before. Newspaper clippings and photographs of 'villagers' with Sachs and Sanchez were proudly shown to us.

In his book, Jeffrey Sachs notes that together with the 'villagers' and the UN Millennium Project, they identified the 'big five' development interventions that would set the Sauri community on a progressive development path. These are: (1) providing modern agricultural inputs, (2) investments in basic health, and (3) education, (4) energy, transport and communication services, (5) safe drinking water and sanitation. These 'big five' interventions were claimed to have been identified together with the 'villagers' who were assembled to respond to pre-prepared questions concerning their wants, desires, and needs that would reflect the eight MDGs (Sachs, 2005: 232-235). Sachs described the appearance of the 'villagers' as thin, malnourished and ill (ibid. 227) which constitutes 'labelling' and 'framing' as discussed earlier in the paper. By the time Jeffrey Sachs arrived in Sauri, plans had already been made on how to 'develop' Sauri; the visit was only for documentation purposes.

Even though the MVP was intended to be initiated in a 'poor' area in order to prove the feasibility and effectiveness of village-level interventions, the sequence of events that occurred before the implementation of the project in Sauri confirms that the choice for the MVP location was influenced by the designers' knowledge of the area and their experience working with the local people of Sauri. Interestingly, some of the staff who joined MVP and used to work previously with ICRAF, advocated the use of agro-forestry technologies (which required the use of non-commoditised biologically reproducible resources) in soil fertility replenishment as more effective. For instance, Sanchez $(1999,2002)$ suggested that the most effective and appropriate approach to soil replenishment, one that can help improve the current African conditions better than those used during the Green Revolution, is a combination of improved fallows, phosphorous and biomass transfer, because they are 'low-tech' and knowledge intensive technologies (Sanchez, 2002: 2020). However, upon joining MVP, Sanchez' focus shifted to the use of inorganic fertilizers (and hybrid maize instead of locally adapted germplasm), which are commoditised resources, to improve soil fertility and raise productivity of land and labour.

MVP chose the project site, as Schlesinger (2007) points out, as an area that was more likely to succeed and become a good example of the possibility of poverty eradication during 'our time' as envisioned by Sachs (2005) and his followers. The MVP designers should have, instead, opted for an area in dire poverty or, even better, one with much less intervention history so that it could exemplify the problem indepth. Since many villages in Sauri sub-location have had the experience of interacting with external development programmes and their agents and given that the area is not that badly off as compared to many other 'poor areas' in Kenya, one could as well say that the project was foreseen or rather expected to be a success in such a location (Schlesinger, 2007: 3). SMV was, therefore, the result of a rather subjective choice of site.

\subsection{SMV's agricultural interventions}

SMV enthusiastically began with a baseline survey in 2004 along with demonstrations on the proper way of using the hybrid technologies such as the agronomic practices. Different types of hybrid seeds were planted in the demonstration farms during the short season in order for the farmers to learn from and choose the types of hybrid seeds to plant during the long season. The community was also organised in to groups/sectors to facilitate the implementation of MVP and these included the agricultural sector. In 2005 the farmers were given free inputs, hybrid seeds and the fertilizers they preferred. Some of the farmers took the inputs and sold them to neighbouring villages as one of the community members pointed out to us:

'most of these fertilizers the community members were receiving from SMV did not go into good use. I know of some people here who would get the fertilizers and sell them to the neighbouring villages, to serious farmers there'.

Not all 'village people' are farmers. Nonetheless, after the long rains in 2005, the farmers realised a bumper harvest of maize which was highly praised. Government high ranking officials accompanied by Jeffrey Sachs and his team from the Earth Institute travelled to Sauri to celebrate the bumper harvest during a big festival (Mutuo et al., 2006). That was the first and last one ever witnessed in Sauri as many of our respondents pointed out. The subsequent distribution of inputs was corrupted as one villager commented:

'Sometimes inputs and seeds would be brought to be shared among the farmers in the right proportion, but you would find that some people would get nothing or get far much less than others. There was a lot of discrimination and corruption and even at time the free inputs were given for money which was not right'.

The farmers were also given improved fallow seeds with the promise that the project would buy the seeds from them. The first time the farmers had the seeds many of them made a lot of money from the seeds. However, once the project stopped buying the seeds, the farmers stopped planting the fallow trees by 2009 even though they contributed to soil fertility replenishment. One of the key informants, a former SMV member of staff, criticised the strategy they used to get farmers to adopt to fallow technology. She said

'the approach given to the ICRAF seeds that we gave to the farmers was wrong. They were told that the seeds would be bought once they were ready and during the time that the seeds were being bought from the farmers, the farmers planted lots of fallow trees but once the seeds were no longer being bought, the farmers stopped planting them. I had a big problem in the villages because of the fallows. Some farmers still plant them, especially the lead farmers, but most of them have stopped planting'.

The farmers were enticed by the financial gains from the fallow trees and particularly the market for seeds that ICRAF had created, and, mostly, did not adopt this strategy for the intended purposes (see also Place et al., 2007a, 2007b; Mango and Hebinck, 2016).

In order to smoothen the adoption of MVP-ideas and technologies and to beneficially transform Sauri from a 'traditional' to a 'modern' entrepreneurial society, the MVP set out to reshape the way the community organised themselves. The maize technologies (hybrid maize and inorganic fertilisers) were at first distributed for free and then offered on condition that the community members organised themselves into formal groups or cooperatives to access the inputs and to market their produce. This attempt ignored local peoples' own agency and their attempts to strengthen their own local ways of social organisation, marketing, and exchange of produce and seeds. To some extent, the 'free gift' approach as a strategy to get farmers to adopt new technologies ignited a 'dependency syndrome' among the farmers who thought that MVP was there to stay and that they would continue getting free inputs. A farmer noted that

'we got used to the free fertilizers and seeds and we did not know that it would come to an end so soon since they had told us they were going to be with us till 2015'.

After the withdrawal of the 'free gifts', most poor farmers could not continue to engage with the MVP-desired development strategy. They, in contrast to the better-off farmers and those in strategic positions of power, distanced themselves from MVP and actively re-engaged with 
local ways of production and organisation. Interestingly, the MVP's intention to transform Sauri facilitated the emergence of assemblages that were desired by its protagonists, but at the same time, it gave way to assemblages that centre on the use of locally available resources and cultural repertoires (Hebinck et al., 2015).

In an effort to get farmers a collective bargain and better markets, MVP introduced a Cooperative System of marketing and grouped farmers according to their status. The project sought to organise farmers more formally towards entrepreneurship that would lead to increase in incomes. This formal organisation would replace the long existing informal forms of exchanges. The farmers were taught how to keep records throughout the production in an effort to turn their farming in to a commercial venture. The Cooperative System was introduced after earlier attempts to link farmers to micro-financial institutions such as SAGA, table banking, and cereal banking failed due to non-repayments of loans. Farmers feared losing their assets that were registered as collaterals in case of failure to repay the loans. The debts created through loans were intended to compel the farmers to sell their produce and get cash to repay the loans.

A Market Service Centre (MSC) was established in 2011 that housed a total of 8 cooperatives which consisted of grain and other producer cooperatives. The cooperatives include Kilimo ni Uhai and Indigent Grain Cooperatives, Gem Horticultural Cooperative, Fish Farming Cooperative, Poultry Cooperatives and Beekeeping and Honey processing Cooperatives. The Indigent Cooperative was meant for the vulnerable farmers who could not afford to purchase inputs. They would receive $25 \mathrm{~kg}$ of DAP (fertilizers), $6 \mathrm{~kg}$ of hybrid seeds and $25 \mathrm{~kg}$ of Urea (for top dressing) through credit. They were required to pay back with a bag of maize $(90 \mathrm{~kg})$ after harvesting. These inputs were way too little for the farmers' needs and thus they would be made to purchase more inputs, or else use fewer inputs. Additionally, the farmers were expected to give an 10 extra kilograms of maize during repayment for transportation. The repayment process always involved force to some extent. The debt collectors, who were also members of the community, would take it upon themselves to assess the farmer's harvest from the farmers' stores and extract the number of bags or gorogoros that the farmer was indebted as the cooperative input loan. They would force their way in whenever a farmer tried to resist. And the farmers felt that they were being harassed by the debt collectors. This contributed to more friction within the community.

Horticultural farmers were also introduced to greenhouse technology in 2010 and given loans to facilitate the acquisition of the greenhouses. This technology did not do well and most of the greenhouses stood empty after a while, fell apart or were used for other purposes such as storing bricks. The SMV field officers were pushed by SMV to make sure that the farmers adopted this technology. As one of the SMV field officer, whom we informally interviewed noted

'farmers were kind of being forced into these technologies. Look, for instance, [at] something like greenhouses technology; when it was introduced in 2010, some farmers were very excited to have them because we explained to them how to manage the greenhouses and the kind of good harvests they could obtain from them. But when the farmers were given to manage them, most of them lost interest and said they did not want greenhouses anymore. We, as the field officers, were instructed to do all we could to make the farmers adopt and sustain them. It has been hard'.

However, some farmers complained about the kind of 'training' they got concerning greenhouses. One of the farmers said that

'They did not really train us on how to operate the greenhouses. They would visit and one time when they came here to review, I told them that I was not trained but they said that whenever we were invited to their meetings, those were the trainings we received (laughing). These are some of the things that discourage us a lot. At times we would find that in the meeting, it was one of those companies that make seeds, fertilizers, pesticides etc. that would talk about their products. It was not really training.'

SMV was busy linking the farmers to the markets for accessing input (as far as greenhouses were concerned) other than working out the underlying challenges in production.

As an exit strategy, SMV adopted a lead farmer concept. Active farmers were selected to be a source of information for the other farmers. They were trained and advised to open up their farms for other farmers to learn from. The Lead Farmer programme was launched in 2013 to provide a better alternative for farmers to acquire new techniques for farming. The lead farmers were trained in technical, communication and leadership skills and are expected to share with others in order to create some change within the community (MDG, 2014:30). The selection criteria were contested though. We analyse these agricultural interventions in the section that follows.

\section{3. 'Our data, our currency ... Keep off!'}

This subsection highlights the highly secretive MVP data and their questionable project evaluation reports that were used to cover the truth about most of the happenings within MVP and to paint a picture of success. The MVP reports and more specifically the SMV reports on impact evaluations were done in a closed and confidential manner. This raises serious doubts about the nature of the data and the kind of realities these reports aimed to convey and to whom. Researchers like us who were not associated with the SMV more broadly were not allowed to access and make use of SMV data. This greatly prohibited critique of data production, and the processing and validation of analysis of impact. Clemens and Demombynes (2013) argue that project data requires an interactive process of external critique. By denying visiting scholars project related data, independent analyses of the impact of the SMV remain undermined. The tendency in the reporting that has been published $^{8}$ endorses a view of the impact of the project that serves the interest of the project bureaucracy so that it can continue to receive funding for development work (Clemens and Demombynes, 2013:12). Thus most projects are compelled to publish impressive reports even though the reality is different.

Demombynes (2012) points out that access to data is a major issue in African development projects. Most of the data collected is never used again after a single progress report is produced. The data is hidden from the public because of its lack of quality or credibility that may trigger questions if it is scrutinised by others. Jerven (2014) for instance points out that most statistical data on the basis of which development policies are designed and adjusted is unreliable and grossly incomplete.

That most data is hidden because of its deficiencies is certainly true of MVP. The project received a lot of criticism on their reports, from its lack of sufficient measures to the lack of data to back up the claims of success. Some MVP reports published were found to be misleading. At times MVP was made to take back some statements of wrong reporting and to rectify mistakes after criticism (Clemens and Demombynes, 2013: 3-7; Pronyk, 2012). How about the false and erroneous reports by MVPs at national level that have not been detected? Clemens and Demombynes (2013) note that their critical review of MVP reports (Clemens and Demombynes, 2011) was only feasible because the Demographic and Health Surveys allowed for an independent assessment of MVP assertions of success (Clemens and Demombynes, 2013: 12). This raises questions as to how the data was collected, ordered and analysed. Interestingly, some of the SMV claims of success are rooted in previous interventions implemented before the launch of SMV. For instance, the farmers who independently applied the Green Revolution package prior to SMV (as documented in Mango, 2002), were presented as SMV success stories during visitor tours to the project site and the

\footnotetext{
${ }^{8}$ Notably in reputable and high impact journals like The Lancet and Science.
} 
farmers introduced to the visitors as SMV farmers (personal observations and interviews).

Moreover, only a few reports on SMV have been published. These include the baseline survey report (Mutuo et al., 2007) and the first annual report (Mutuo et al., 2006) that reported and celebrated the bumper harvests. ${ }^{9}$ These bumper harvests were realised in the 2005/ 2006 and 2006/2007 agricultural season, with yields of respectively 4.9 and 6.2 tons per hectare (Mutuo et al., 2006: 11; Haro, 2014: 255). The first bumper harvest was celebrated in Sauri on July 21, 2005, as a major success of SMV and Jeffrey Sachs, representatives of UNESCO, and high ranking Kenyan government officials attended the festivities (Mutuo et al., 2006:10). The reports do not mention that these yields were, however, only realised during the first two years of SMV, the period when farmers received free inputs (e.g. improved hybrid maize seeds and inorganic fertilizer) in full during the first year, and a half in the second year of implementation. After that yields dropped substantially and the much-heralded yield increases did not continue. Many of our informants attested to this during interviews. In line with the MVP-culture of not sharing information or data, SMV did not publish any more yield data which would be their most highlighted criteria for success. Wanjala (2016) and Wanjala and Muradian (2013) point out that the project generated significant increases in yields but no significant increase in monetary income. Farmers still talked about those yields which were high at that time particularly when compared to the period before SMV implementation. In contrast to Wanjala (2016), we find the current situation in Sauri in terms of yields far worse when compared with the pre-MVP situation. Some farmers attribute this to the degraded soils, especially after the introduction of chemical fertilisers which many believe has deteriorated markedly in quality (Mango, 2002: 167). Odongo, one of the farmers Mango interviewed in 2000, stated that the fertilizer he has been using since the 1940s has been good until recently, but the quality of today's fertilizer does not improve the yield of the maize grown as it did when hybrid maize was introduced. On-farm research by CARE and KEFRI confirm this. Abednego, interviewed in 2000 by Nelson Mango explained the fertilizer issue as follows:

'We lack proper inputs, this is what is causing low productivity. The kind of fertiliser we receive nowadays is not good and that is why some farmers say it spoils the soil. I think there is something wrong with the fertiliser we receive nowadays. Since we cannot afford to buy a whole bag of fertiliser, traders divide fertiliser in this bag into small packages that are affordable to us. Maybe during this time, they add other things not known to us' (Mango, 2002: 167).

MVP data was not accessible to unscrutinised and 'unqualified' researchers who sought their data. A key informant told us that in order to gain access to SMV data, one had to be vetted first and research objectives had to be assessed before being given any access to data or other support by MVP officials. Most of those who got MVP support for their studies usually had their study objectives aligned to MVP goals with future results in support of the project's claims. We confirmed this information as correct when we sought access to SMV data ourselves and visited the SMV field office in Sauri and the regional office in Kisumu. At the regional office, we were advised to send an email that explained our research and the kind of data we needed. After our email

\footnotetext{
${ }^{9}$ The notion of bumper harvest is misleading. The yield figures provided in the MVP reports are presented and compared with previous years. In addition, the concept yield is one-dimensionally understood and applied: what is harvested is measured per unit of land or labour. In contrast, a multidimensional concept of yield we found in the villages is that it should include not only what the Annual Report acknowledges as harvested and stored and also as green (so-called unripe) maize (Mutuo et al., 2006: 11), but, more importantly in our view, the nutritious value of maize. Women in particular point out that their local maize varieties are far more ('twice as much') nutritious than the hybrid maize varieties preferred by MVP (Hebinck et al., 2015; Mango, 2002). It is quite well known that local or indigenous varieties of plants can be up to $200 \%$ more nutritious than commercially cultivated varieties (Committee on World Food Security, nd.).
}

requesting copies of annual reports and other data that had been collected over the previous five years or so, communications between us and the regional office stopped immediately. No response was ever given. We did not qualify to access their data. However, as pointed out earlier, we managed informally to access data and some unofficial reports from MVP field staff.

\section{Assemblage dynamics and practices}

At least six assemblage practices stand out when considering the dynamics of the MVP assemblage as exemplified by SMV. (1) Everyday issues of (un)equal distribution of power, socio-political struggles for villagers to decide own futures and whose knowledge and realities counts in decision making (Chambers, 1983) are isolated from the technical questions. Ferguson (1990), Escobar (2011) and Mosse (2005) ascribe depoliticizing effects to this process. (2) Depoliticizing or rendering technical not only rearranges and misinterprets local realities through applying standardized assessment procedures to legitimize certain interventions but simultaneously it obscures alternative solutions and practices. (3) The villages and communities are treated as spaces with no histories, with no records of development. (4) Previous interventions to transform or improve development conditions are largely ignored like the robust, novel practices that emerge at the local level. Apparently, not much has happened in the villages in which there have been interventions over the last so many years and that the available collective and individual agency is not taken into account. (5) Rendering technical in this way takes the focus of attention away from local dynamics and away from the place and context where possible solutions can be found and to an extent are practiced already. (6) After the MVP was launched as a high profile project that was deemed too important to fail, it produced data and reports, to keep track of its impacts, for internal circulation only and sealed off from the broader public. MVP only published positive but questionable reports of its successes. Some success stories of farmers turned into entrepreneurial farmers were claimed as the result of SMV, while our ex ante-MVP studies reveal that they already embraced such a strategy (Mango, 2002). These reports served to sweep its inefficiencies under the carpet and were valuable tools to prove and convince the donor community that MDGs are achievable and that the continuity of funding over a long period of time is essential.

The fixing of solutions required the community to be reordered to comply with the formal rules for purposes of governing and control. This had major, even dramatic, impacts at the community level as we will elaborate in some detail in this section. As a result of MVP interventions, the community has experienced a deepening of existing inequalities and conflicts, especially due to elite capture of intervention benefits, mainly the agricultural inputs. In addition, enmity among the community members crept in generally injuring the social relations among the members. This is not to indicate that MVP did not have any positive effects in Sauri. In fact, the farmers picked up what they considered important to them and have continued to use it, for instance, the land preparation techniques and line planting regardless of whether they are planting the local maize varieties or the hybrid seeds. These reassembling practices and the dynamics these display are key practices for the analysis of the limits of planned agrarian change.

The labelling and framing of villagers as 'hungry, thin and impoverished' (Sachs, 2005: 227) and more importantly, the lumping together of Sauri villagers as a mass of homogeneous entities is typical for MVP. A village in Sub-Saharan Africa, however, consists of groups and people that are socially differentiated in terms of age, class, and gender. Some of the villagers may be influential business-oriented farmers and traders who already engage in global markets while others may be small scale farmers who depend on family labour and largely produce for themselves and their families, and in case of a surplus, for local markets (Carr, 2008: 336; Mango, 2002). Again others engage in multiple livelihoods and spent considerable time in urban environments 
keeping ties with their rural homes (Ramisch, 2014, 2015).

The MVP assemblage in Sauri seriously lacked context specificity as development is perceived to be a universal process as a result of which it cannot adequately cope with complexity (Umans and Arce, 2014: 342). The already existing relations in rural development are affected by elements inserted into the farmers' assemblages that mainly appear in the form of capital (e.g. loans), knowledge (e.g. modern science) and transfer of technology (e.g. introduction of Green Revolution-styled packages). Such insertions disturb and fracture the already existing and rooted relational organisations. MVP was more concerned about reproducing a certain ideology than the transformation of the relations of poverty and inequality (Wilson, 2016:5). It can be argued that the MVP assemblage was actually not so keen to fix solutions but to paint a picture of success to exemplify the achievability of the MDGs and this equates to assembling success.

MVP did not engage in a critical assessment of the previously implemented development-styles. Farmers in Sauri were trained in the 'modern' ways of farming and supplied with hybrid seeds and fertilizers (Mutuo et al., 2006). MVP also reintroduced the use of the fallow technology for soil replenishment that was initially introduced by the International Centre for Research in Agro-forestry (ICRAF) in the mid1990s (Kiptot et al., 2006, 2007; Mutuo et al., 2006; Sanchez, 1999), forming a continuation of the same and taking along with it ICRAF's failures to install agro-forestry techniques within the farming community (Kiptot et al. 2006, 2007; Place et al. 2007a, b; Mango and Hebinck, 2016).

The strategy of SMV to fix solutions for the perceived need for formal channels of distribution such as the cooperatives and the cereal banking schemes had dramatic results. By the time of this study, most farmers had distanced themselves from the Cooperative System. According to the manager of the indigent cooperative society, about half of the cooperative members withdrew within a year after joining the cooperative. He said

"when we started the indigent cooperative, there were 4000 members from Sauri cluster but now we are around 2000 members. One of the reasons for drop out is that there are joyriders; people who are not ready for the program. They do not use the inputs they are given but instead sell them immediately they receive them. They thus do not get to pay back the one bag of maize expected from them. I think it's a complex thing about how people behave. Others use them well, get good harvests but fail to pay back and thus they are disqualified from the cooperatives".

In the same vein, the cereal banking scheme that preceded the Cooperative System was established to make it possible for farmers to reap the benefits of receiving higher prices for their grains after cumulative storage (Sanchez et al., 2009: 39; See also Wanjala, 2016:133-135). However, this never worked out. Only one of the initial 11 cereal banks introduced in the 11 villages was still operational in 2009 (Wanjala, 2016: 134) and by the time of our research in Sauri, there was no cereal bank. Due to mistrust, abuse of power and corruption of the members of the community responsible for the cereal banking operations, it collapsed causing massive loss of maize grains to the farmers. Various actors who engaged with the cereal bank had their own diverging interests. Conflicts erupted, exposing deep rooted historical differences and inequalities within the community. Many of our respondents cited abuse of power by those in leadership positions as the main reason for the disintegration of the community structures and member withdrawals from the cereal banking system. Joseph, who was in charge of the Sauri Community Centre that initially housed the cereal bank stated that

"when the cereal bank was established, we collected 1075 bags of maize and the MVP promised to give us additional Kshs. 100,000 (approx. \$ 1000) for buying more maize from the farmers to add to the bags we had collected and then they would sell the maize for us.
Our maize was sold and we never got anything. These Millennium people really disappointed us. People then refused the whole thing about cereal banking. Farmers had already contributed with varying quantities of maize wholeheartedly and with much hope for benefits. I lost five bags of maize that time to the 'cereal bank', it was painful".

One thing that MVP did not realize is that not all community members are agricultural entrepreneurs. Some cultivate maize to feed themselves while others are more inclined to be entrepreneurial and actively sell their surpluses. Maize cultivation also has an important symbolic role (Ramisch, 2014: 22; Cohen and Atieno-Odhiambho, 1989; Hebinck et al., 2015) such that some farmers plant maize to fulfil the expectations of the community as everyone is expected to cultivate the land to feed their families. In the effort to 'enlighten' farmers and to 'make' them entrepreneurs, MVP unintentionally opened doors for corruption, social exclusion, and mistrust.

SMV activities were liable to elite capture of inputs that passed unnoticed. At the onset of the project, all farmers within the MVP village were eligible for free hybrid seeds and fertilizers that reduced to half the following year and was scrapped to give way to self-reliance during the third year of the project. The farmers were introduced to the credit systems along with the reduction of the supply of free inputs. Those who could not afford to repay the loans quit the arrangement. The better-off farmers with relatively large plots of land benefitted more from the whole credit arrangement because they could afford to buy the required subsidized inputs. In fact, one of them stated that

"I have never planted without the use of fertilisers because I always have the money to buy them. I do not really understand why my neighbours keep claiming that fertilizers are too expensive and yet the soils are so depleted such that without fertilisers one cannot get any good harvest".

The hybrid package was thus more applicable to the able farmers with alternative cash income but not to the poorest ones. On the other hand, the elites had an upper hand in access to inputs and Joseph pointed out that

"the members of indigent cooperative society are supposed to be the vulnerable members of the community who cannot afford to buy inputs by themselves, but you will find other well-up people benefitting from this, even a full professor".

The soils of the poor farmers deteriorated from the initial use of the free fertilisers from SMV. Eventually, they could not harvest as much as they used to when they planted without fertilisers before MVP implementation. Since they reverted to planting the local maize varieties, their seeds could not yield as much without fertilisers and yet they could not afford them. The benefits of the schemes set out to help the vulnerable ended up benefitting the wealthier members who could corrupt their ways out through privileged access to key resources. Thus the intended benefits of the project did not really trickle down to the neediest people in the villages, contributing to further class division.

The way SMV was implemented intensified the relations of power inequalities and conflicts that existed. For instance, in Sauri two prominent clans make up the social fabric: the Kalanyo and the Kathomo clan, which have had differences historically. It is said that the Kathomo clan is not originally from Sauri but migrated from another part of Siaya region known as Wagai. The Kathomo clan members are said to be more aggressive in leading and grabbing other opportunities that come their way. The Kalanyo clan members make up the majority members of the community, and it is claimed that they are less aggressive compared to the Kathomo clan members. From this perceived narrative, the SMV provided an opportunity for the Kathomos to exercise their aggressiveness and rise into positions of power, something that did not go down well with the larger clan. The Kalanyo clan is blamed for trying to prevent other clans from becoming involved in any development 
activities within the community, with claims that the area is originally theirs. ${ }^{10}$ The informants pointed out that, when MVP was implemented, these conflicts became worse and people accused each other of many wrong doings. The Kathomos managed to manoeuvre themselves in positions of power and most of them became lead farmers who usually were the first to receive information from MVP. In most cases, that information was relayed only to the farmers within their lineage. Quite a few farmers complained that 'things were just happening and no one bothered to update them'. Meetings would be held, decisions made and the farmers would not know of it except for a few well connected farmers. The passing of such information was selectively done by those in charge. Only a few farmers would be informed to attend meetings. One of the farmers, for instance, explained to us that some white small groundnuts were given for distribution among the farmers but only a few who were informed about it received them. Some leaders kept the groundnuts for themselves and only shared with their close friends and relatives. This resembles situations of corruption during the implementation of ICRAF's Agro-forestry programmes during the 1990s and early 2000's. Community leaders were accused of keeping the imported rock phosphate for themselves or for sale. The accusation were real and observed by Mango and Hebinck during fieldwork in 2004 in Sauri (see also Mango, 2002: 268-270).

Situations like these exacerbated the existing enmity amongst and between people in the village to an extent that people were not talking to each other anymore. The community was also involved in bitter conflicts over leadership within the MVP structure. This is in contrast to situations before MVP set foot in Sauri and prior to similar programmes such as those managed and implemented by ICRAF. In situations of conflict over certain issues (e.g. such as those over land, not sharing resources) but still people talked to each other and engaged in some activities together (Hebinck and Mango, 2008; see also Haro, 2014: 341-349.

Additionally, the use of the hierarchical structure of the community intensified the existing inequalities amongst and between people in the village. The leaders such as chiefs, assistant chiefs or headmen as well as community elites are in more powerful positions than other members of the community and they are mostly the community gatekeepers. The project goods and services flow along those lines. Most development projects connect with these power holders to parachute their project ideas and to push transformation in ways the project desires. This relationship benefits those people in power who are economically endowed as well as their close allies which results in unequal sharing in the community. This also explains why the so-called unintended consequences such as 'elite capture' occur during project implementation (Platteau, 2004; Panda, 2014; Rigon, 2014).

Some of the strategies SMV used as sustainability measures resulted in more tensions, jealousy, and undermining of social relations. The MVP adopted the ICRAF style of investing in a few community members to act as examples and as lead farmers from whom other community members would learn and who they would emulate (Kiptot et al., 2006: 168). MVP adopted the lead or master farmer concept and launched it in 2013 to ensure that innovations (e.g. new farming techniques) that were introduced would trickle down. The lead farmers were specifically trained in technical, communication and leadership skills with the hope of ensuring sustainability (MDG, 2014). ICRAF had set up such arrangement to facilitate the adoption of fallow tree agro-forestry technology. During our ex-ante studies, these lead farmers were famously called 'ICRAF-agents'. They were easy to spot in the landscape as most $4 \times 4$ tracks would lead to their homesteads, tracks along which celebrities like ambassadors and ministers would drive to visit their fields (Mango, 2002; Place et al., 2007b). They attended seminars and

\footnotetext{
${ }^{10}$ This is part of the complex history of settlement that followed the migration of the Luo from Southern Sudan into what is now west Kenya (or Luoland). See (Mango (2002): 35-380). Clans were engaged in fights over control of the new territory. These sentiments still play a role to date.
}

workshops and selected those who were to attend meetings and as well as seminars. People did not like the 'agents' as they were given preferential treatment by NGO's and donor agencies but liked the ICRAF staff because they were getting free inputs from them (Place et al., 2007b). The approach of picking a few farmers to work with them created tensions among the community members. These farmers were seen as having been favoured, a perception that aroused jealousy in the community hence upsetting existing social relationships (Mango, 2002; Place et al., 2005). This strategy had previously caused a stir among the community members who cited favouritism of ICRAF towards the 'ICRAF-agents' whose selection again was linked to a network of kinship relations and patronage. It yielded similar results as before.

The Solution-Fix of MVP is evident in the choice of what key agricultural resources to introduce to meet the targets and objectives of MVP and the MDGs. Whereas MVP opted for an approach inspired by the Green Revolution that hinges on introducing and spreading the application of commoditised resources (e.g. hybrid maize, inorganic fertilizer), the predominant tendency in Sauri and surrounding villages is that people continue to rely on locally produced, enriched and exchanged 'local' maize seeds and farmyard manure. In times of food insecurity, pressure on monetary incomes, malfunctioning markets, the introduction of resources that do not resonate with the local socio-ecological environments is not conducive to attempts to enhance rural livelihoods. The introduction of such resources does not contribute to or support the need for farmers and their families to set an independent pace for themselves that hinges on (re)building and relying on their own social networks and (re)producing their own productive resources. This is very much like the struggle for (relative) autonomy in order to reduce dependency that is so characteristic of peasant forms of production (van der Ploeg, 2010). Farmers in Sauri now struggle to distance themselves from the market and input supply markets and cooperatives that were introduced by MVP; instead they re-engage with the resources they know and can easily access and exchange amongst themselves without engaging with commodity markets. These resources, and notably the local maize varieties are trusted and their use embedded in the local cultural repertoires; more importantly perhaps is that they are found to be more tasty, nutritious and easier to plant when compared to improved maize seed (Mango, 2002; Hebinck et al., 2015). Farmers realised especially that the marketing cooperatives and loaning schemes could not adequately address their problems. In fact, according to many respondents, the farmers experienced a great loss when operating through the formal systems introduced by experts, the state and donor organisations (Haro, 2014). Some of them thus chose to disengage and form their own groups that they thought would be more beneficial in the end.

\section{Conclusion}

This paper has explored, from an assemblage perspective, the implementation of the Millennium Villages Project (MVP) in Sauri. The assemblage that emanated from the desire to accelerate the achievement of the MDG's is characterised by great discrepancies between policy objectives and implementation, and between planning and the existing everyday realities in the villages. The SMV assembled elements in such a way that it extended the modernisation of development discourse that has been in existence for decades. Centrally and externally coordinated interventions' from above', bound by time and budget and guided by a practice that aim to fix solutions that rarely resonates with the predominant local conditions, are often ineffective, inefficient and short lasting. MVP as exemplified by SMV unfolded as a continuation of the preceding and globally applied and implemented development strategies such as IRD, SAP and the Green Revolution.

We also showed that the MVP strategy to accelerate achieving the MDGs did not generate lasting, sustainable transformations, thus 'twisting' its application of the fixing of solutions. Our analysis points to a set of problematic strategies that are hidden within the fixing practice and to a haste to assemble success for exemplification purposes. 
Claiming success was facilitated (in part) by the subjective choice of the 'right' site for the project implementation and distribution of free inputs. This forging of alignments and the management of failures of the assemblage through questionable reporting of success stories and data secrecy emerge as typical for the SMV assemblage. The reporting specifically serves as a cover up for the failure to achieve stated objectives and an attempt to secure funds to extend and intensify the MVP approach. The MVP-style of working in Sauri created many tensions and rifts within the community. We have shown how it elicited favouritism, facilitated the elite capture of input, an exacerbation of existing inequalities with a resultant fracturing of the community. The questionable reporting of the project results constitutes a display of ignorance about what was really happening in a locale where the modernising of rural communities through rendering technical was met with suspicion, rejection, active engagement and a reassembling of introduced ideas and technologies.

We have argued that the unpredictability of 'assemblage practices' need to be taken into account. We showed, for instance, that SMV generated contradictory processes that evolved side by side. While SMV created opportunities for elite capture it simultaneously created space for a continuation of localised assembled forms of modernity. These latter phenomena pivot in villages like Sauri on gaining and regaining strength in the generation and enrichment of locally available resources such as the use of local seed varieties and farmyard manure. Processes of commoditisation occur alongside processes of non-commoditisation. The former requires entrepreneurship as preferred by SMV; the latter requires developing locally accepted and adapted skills that provide some historical continuities. The experience of MVP in Sauri reiterates that agrarian change is non-linear and produces contrasting trajectories of change. Social change cannot simply be engineered and planned. Outcomes cannot simply be measured by the degree of adoption of externally introduced resources such as technologies and institutions.

The value of viewing MVP and related interventions through an assemblage lens is that it allows a clear understanding of why this is and why reassembling is an important practice of assemblages we need to take into consideration. Change - or development - is mediated through social processes such as local values, historically rooted experiences and cultural repertoires. It is also mediated by the intensity and nature of the interactions between experts and other interveners with the socalled 'target' communities and the inherent encounter of scientific and local bodies of knowledge. Perhaps we have to come to terms with the fact that agrarian transformation largely, though not exclusively, comes from within. Despite the intended stabilising effect of MVP on Sauri's socio-technical fabric, robust or promising assemblages continue to emerge that hinge on localised cultural repertoires and institutions as well as on a strong belief in the locally available resources such as local maize varieties and soil fertility replenishment practices. Our longitudinal studies confirm that farmers even after initial enthusiasm continue to trust and rely on using and enriching their own resources whose use is embedded in locally shared and accepted cultural norms, in order for them to reproduce what they can and share among themselves. Hence we argue for these factors to be regarded as relevant, productive and useful as starting points for a 'fit-in-context' approach to pursuing development rather than through interventions. This would render assemblages that potentially appreciate fully the capabilities of human and non-human actors within the villages. Such assemblages do not relate to the villages as external actors.

\section{Acknowledgement}

We appreciated comments given at the Conference 'Governance by Sustainable Development Goals' Amsterdam, University of Amsterdam, 26-28 June 2016 and the 'Global governance/politics, climate justice \& agrarian/social justice: linkages and challenges. An International Colloquium', The Hague, Institute of Social Studies, February 4, 2016. We also thank Joost Jongerden for commenting an earlier draft and
Wendy Woodward for copy-editing and proof reading. Nel de Vink made the maps included in this article. Comments by the editor and the two anonymous reviewers were extremely helpful in restructuring the original manuscript.

\section{Appendix A. Supplementary data}

Supplementary data related to this article can be found at http://dx. doi.org/10.1016/j.jrurstud.2017.12.019.

\section{References}

Arce, A., Long, N., 2000. Anthropology, Development and Modernities: Exploring Discourses, Counter-tendencies and Violence. Routledge, London.

Ashley, C., Maxwell, S., 2002. Rethinking rural development. Dev. Pol. Rev. 19, 395-425. Binagwaho, A., Sachs, J., 2005. Investing in Development: a Practical Plan to Achieve the Millennium Development Goals. Earthscan, London.

Burawoy, M., 2003. Revisits: an outline of a theory of reflexive ethnography. Am. Socio. Rev. 68, 645-679.

Cabral, L., Farrington, J., Ludi, E., 2006. The Millennium Villages Project-a new approach to ending rural poverty in Africa. Natural Resource Perspectives 1-4 ODI 101.

Carlsen, J., 1980. Economic and Social Transformation in Rural Kenya. Scandinavian Institute of African Studies, Uppsala.

Carr, E., 2008. The millennium village project and African development problems and potentials. Prog. Dev. Stud. 8, 333-344.

Chambers, R., 1997. Whose Reality Counts? Putting the First Last. Intermediate Technology Publications, London.

Chambers, R., 1983. Rural Development : Putting the Last First. Longman, London.

Clemens, M., Demombynes, G., 2011. When does rigorous impact evaluation make a difference? The case of the Millennium Villages. J. Dev. Effect. 3, 305-339.

Clemens, M., Demombynes, G., 2013. The New Transparency in Development Economics: Lessons from the Millennium Villages Controversy. CGD Working Paper 342. Center for Global Development, Washington, DC.

Clemens, M., Kenny, C., Moss, T., 2007. The trouble with the MDGs: confronting expectations of aid and development success. World Dev. 35, 735-751.

Cohen, D., Atieno Odhiambo, E., 1989. Siaya. The Historical Anthropology of an African Landscape. James Currey Publishers, London.

Committee on World Food Security, n.d. How to Make Responsible Investments in Agriculture and Food Systems. FAO/CFS, Rome.

Crowley, E., 2000. Agrarian change and the changing relationships between toil and soil in Maragoli, western Kenya (1900-1994). Hum. Ecol. 28, 383-414.

Deckelbaum, R., Palm, C., Mutuo, P., DeClerck, F., 2006. Econutrition: implementation models from the millennium villages project in Africa. Food Nutr. Bull. 27, 335-342.

Deleuze, G., Guattari, F., 1987. A Thousand Plateaus. University of Minnesota Press, Minneapolis.

Demombynes, G., 2012. Opening up Microdata Access in Africa. World bank, Washington DC Available at: http://blogs.worldbank.org/impactevaluations/openingupmicrodata.

Denning, G., Kabambe, P., Sanchez, P., Malik, A., Flor, R., Harawa, R., Nkhoma, P., Zamba, C., Banda, C., Magombo, C., Keating, M., Wangila, J., Sachs, J., 2009. Input subsidies to improve smallholder maize productivity in Malawi: toward an African Green Revolution. PLoS Biol. 7, 2-11.

DFID, 2002. Eliminating Hunger: Strategy for Achieving the Millennium Development Goal on Hunger. DFID, London.

Earth-Institute, n.d. http://agriculture.columbia.edu/about-us/people-at-agcenter/full time staff/psanchez/Columbia University. Retrieved on 21/06/2014.

Easterly, W., 2009. How the millennium development goals are unfair to Africa. World Dev. 37, 26-35.

Ellis, F., Biggs, S., 2001. Evolving themes in rural development 1950s-2000. Dev. Pol. Rev. 19, 437-448.

Escobar, A., 2011. Problematization of Poverty; a Tale of Three Worlds and Development in Encountering Development: the Making and Unmaking of the Third World. Princeton University Press, Princeton.

Ferguson, J., 1990. The Anti-politics Machine: "development", Depoliticization, and Bureaucratic Power in Lesotho. Cambridge University Press, Cambridge.

Geertz, G., 1995. After the Fact: Two Countries. Four Decades. One Anthropologist. Harvard University Press, Cambridge MA.

Griffin, K., 1979. The Political Economy of Agrarian Change. Cambridge University Press, Cambridge.

Haro, L., 2014. The End(s) of the End of Poverty. Unpublished Ph.D. thesis. Duke University. Department of Cultural Anthropology, Durham.

Harvey, D., 2005. A Brief History of Neoliberalism. Oxford University Press.

Harvey, D., 2009. The 'new' Imperialism: Accumulation by Dispossession. Socialist register 40.

Hay, M., 1972. Economic change in late nineteenth century Kowe, western Kenya. In: Ogot, B. (Ed.), Economic and Social History of East Africa. Kenya Literature Bureau, Nairobi.

Hebinck, P., 2001. Maize and socio-technical regimes. In: Hebinck, P., Verschoor, G. (Eds.), Resonances and Dissonances in Development. Actor, Networks and Cultural Repertoires. Van Gorcum, Assen, pp. 119-139.

Hebinck, P., Mango, N., 2008. Land and embedded rights: an analysis of land conflicts in Luoland, Western Kenya. In: Abbink, G.J., van Dokkum, A. (Eds.), Dilemmas of 
Development: Conflicts of Interest and Their Resolutions in Modernizing Africa. African.

Hebinck, P., Mango, N., Kimanthi, H., 2015. Local maize practices and the cultures of seed in Luoland, West Kenya. In: Dessein, J., Battaglini, E., Horlings, L. (Eds.), Cultural Sustainability and Regional Development: Theories and Practices of Territorialisation. Routledge, London, pp. 206-219.

Herbert-Cheshire, L., Higgins, V., 2004. From risky to responsible: expert knowledge and the governing of community-led rural development. J. Rural Stud. 20, 289-302.

Heyer, J., 1975. The origins of regional inequalities in smallholder agriculture in Kenya, 1920-1973. E. Afr. J. Rural Dev 8, 142-181.

Hobart, M., 1993. Introduction: the growth of ignorance? In: Hobart, M. (Ed.), An Anthropological Critique of Development: the Growth of Ignorance. Routledge, London, pp. 1-30.

Hulme, D., 2009. The Millennium Development Goals (MDGs): a Short History of the World's Biggest Promise. BWPI Working Paper 100. Brooks World Poverty Institute, Manchester.

Hulme, D., 2010. Lessons from the making of the MDGs: human development meets results-based management in an unfair world. IDS Bull. 41, 15-25.

Hyden, G., 1983. No Shortcuts to Progress. African Development Management in Perspective. Heinemann, London.

Jerven, M., 2014. The political economy of agricultural statistics and input subsidies: evidence from India, Nigeria and Malawi. J. Agrar. Change 11, 129-145.

Kanter, A., Negin, J., Olayo, B., Bukachi, F., Johnson, E., Sachs, S., 2009. Millennium global village-net: bringing together millennium villages throughout sub-Saharan Africa. Int. J. Med. Inf. 78, 802-807.

Kimanthi, H., 2014. Interlocking and Distancing Processes: an Analysis of Farmers' Interactions with Introduced Crop Production Technologies in Sauri Millennium Village, Kenya. Unpublished Master's thesis. Wageningen University, Wageningen.

Kiptot, E., Franzel, S., Hebinck, P., Richards, P., 2006. Sharing seed and knowledge: farmer to farmer dissemination of agroforestry technologies in Western Kenya. Agrofor. Syst. 68, 167-179.

Kiptot, E., Hebinck, P., Franzel, S., Richards, P., 2007. Adopters, testers or Pseudoadopters? Dynamics of the use of improved tree fallows by farmers in western Kenya. Agric. Syst. 94, 509-519.

Kitching, G., 1980. Class and Economic Change in Kenya - the Making of an African Petite-bourgeoisie, 1905-1970. Yale University Press, New Haven.

Leupolt, M., 1977. Integrated rural development: key elements of an integrated rural development strategy. Sociol. Rural. 17, 7-28.

Li, T., 2007a. Practices of assemblage and community forest management. Econ. Soc. 36, 263-293.

Li, T., 2007b. The Will to Improve: Governmentality, Development, and the Practice of Politics. Duke, Durham NC.

Li, T., 2014. Land's End: Capitalist Relations on an Indigenous Frontier. Duke Press, Durham.

Long, N., 1977. An Introduction to the Sociology of Rural Development. Tavistock Publications, London.

Long, N., 2001. Development Sociology: Actor Perspectives. Routledge, London.

Mango, N., 1996. Farmers Responses to the Agrarian Crisis in Siaya District, Kenya: an Analysis of How Farmers 'internalise' Induced Technology Interventions in Dairy Farming. Unpublished M.Sc. Thesis. Wageningen University, Wageningen.

Mango, N., 1999. Integrated Soil Fertility Management in Siaya District, Kenya. Managing Africa's Soils. IIED, London.

Mango, N., 2002. Husbanding the Land. Agrarian Development and Socio-technical Change in Luoland, Kenya. Unpublished Ph.D. thesis Rural Development Sociology. Wageningen University, Wageningen.

Mango, N., Hebinck, P., 2004. Cultural repertoires and socio-technological regimes: a case study of local and modern varieties of maize in Luoland, West Kenya. In: Wiskerke, H., Ploeg, J.D., van der, J.D. (Eds.), Seeds of Transition. Essays on Novelty Production, Niches and Regimes in Agriculture. Royal Van Gorcum, Assen, pp. 285-319.

Mango, N., Hebinck, P., 2016. Agroforestry: a second soil fertility paradigm? A case of soil fertility management in Western Kenya. Cogent Social Sciences 2, 1-17.

McFarlane, C., 2009. Translocal assemblages: Space, power and social movements. Geoforum 40, 561-567.

McFarlane, C., Anderson, B., 2011. Thinking with assemblage. Area 43, 162-164.

MDG, 2014. A Future Free from Poverty. Annual report 2014. . www.globalcenters. columbia.edu/nairobi retrieved on 21.05.2014.

Mosse, D., 2005. Cultivating Development: an Ethnography of Aid Policy and Practice. Pluto Press, London.

Mutuo, P., Okoth, H., Makomere, C., Oule, J., Oduong, G., Ombai, W., Wariero, J., Akinyi, B., 2006. Annual Report for Sauri, Kenya Millennium Research Village July 2005June 2006. Earth Institute, Columbia University, New York.

Mutuo, P., Palm, C., Konecky, B., Wang, K., Eliud Lelerai, E., Adkins, S., Nabie, B., B.A., Y., Deckelbaum, R., DeClerck, R., Gauvey-Kern, K., Thomas Kaluzny, M., Korves, C., Modi, V., M, J.N., Okoth, H., Biko Okoth, S., Okumu, B., Oule, J., Pillai, D., Place, F., Rumbaitis, J., Rio, D., Sachs, J., Emma Sacks, S., Simcock, X., Tozan, J., Wangila, A., 2007. Baseline Report-millennium Research Village Sauri, Kenya. Earth Institute, Columbia University, New York.

Nziguheba, G., Palm, C., Berhe, T., et al., 2010. The African green revolution: results from the millennium villages project. Adv. Agron. 109, 75-115.

Obhudo, R., Waller, P., 1976. Periodic Markets, Urbanization and Regional Planning. A Case Study from Western Kenya. Green Wood Press, Westport.

ODI, 1979. Integrated Development. Briefing Paper Nr. 4. ODI, London. .

Ogutu, M.A., 1971. The role of cotton in Nyanza: 1945-1965. East Afr. J. 9-14.

Olivier de Sardan, J.P., 2006. Anthropology and Development: Understanding
Contemporary Social Change. Zed Press, London.

Panda, S., 2014. Political connections and elite capture in a poverty alleviation programme in India. J. Dev. Stud. 51, 50-65.

Pearse, A., 1977. Technology and peasant production: Reflections on a global study. Dev. Change 8, 125-159.

Pearse, A., 1980. Seeds of Plenty, Seeds of Wants. UNRISD, Geneva.

Place, F., Adato, M., Hebinck, P., Omosa, M., 2005. The Impact of Agroforestry-based Soil Fertility Replenishment Practices on the Poor in Western Kenya. Research Report. IFPRI, Washington, pp. 166

Place, F., Adato, M., Hebinck, P., 2007a. Understanding rural poverty and investment in agriculture: an assessment of integrated quantitative and qualitative research in western Kenya. World Dev. 35, 312-325.

Place, F., Adato, M., Hebinck, P., Omosa, M., 2007b. The impact of agroforestry-based soil fertility, replenishment practices on the poor in western, Kenya. In: Adato, M., Meinzen-Dick, R. (Eds.), Agricultural Research and Poverty: Economic and Social Impacts in Six Countries. Johns Hopkins University Press, New York, pp. 149-198.

Platteau, J.P., 2004. Monitoring elite capturing in community-driven development. Dev. Change 35, 223-246.

Pronyk, P., 2012. Errors in a paper on the millennium villages project. Lancet 369, 1946.

Pronyk, P., Muniz, M., Nemser, B., Somers, M., McClellan, L., Palm, C., Huynh, U., Amor, Y., Begashaw, B., McArthur, J., 2012. The effect of an integrated multisector model for achieving the Millennium Development Goals and improving child survival in rural sub-Saharan Africa: a non-randomised controlled assessment. Lancet 379, 2179-2188.

Ramisch, J., 2014. 'We will not farm like our fathers did'. Multilocational livelihoods, cell phones, and the continuing challenge of rural development in western Kenya. In: Sick, D. (Ed.), Rural Livelihoods, Regional Economies, and Processes of Change. Routledge, London, pp. 1-25.

Ramisch, J., 2015. "Never at ease": cell phones, multi locational households, and the metabolic rift in western Kenya. Agric. Hum. Val. 33, 979-995.

Rigon, A., 2014. Building local governance: participation and elite capture in slum-upgrading in Kenya. Dev. Change 45, 257-283.

Sachs, J., 2005. The End of Poverty: Economic Possibilities for Our Time. Penguin Press, New York.

Sachs, J., McArthur, J., 2005. The millennium project: a plan for meeting the millennium development goals. Lancet 365, 347-353.

Sanchez, P., 1999. Improved fallows come of age in the tropics. Agrofor. Syst. 47, 3-12.

Sanchez, P., 2002. Soil fertility and hunger in Africa. Science 295, 2019-2020.

Sanchez, P., 2006. The African Green Revolution and the Millennium Villages Project. Presentation at ODI Programme Agricultural Development \& Policy, Overseas Development Institute (ODI) on November 2, 2006. https://www.odi.org/events/ 162-african-green-revolution-millennium-villages-project London.

Sanchez, P., Denning, G., Nziguheba, G., 2009. The African green revolution moves forward. Food Struct. 1, 37-44.

Sanchez, P., Palm, C., Sachs, J., Denning, G., Flor, R., Harawa, R., Jama, B., Kiflemariam, T., Konecky, B., Kozar, R., 2007. The African millennium villages. Proc. Natl. Acad. Sci. Unit. States Am. 104, 16775-16780.

Schlesinger, V., 2007. The Continuation of Poverty. Rebranding Foreign Aid in Kenya. pp. 58-66 HARPERS 1884.

Scott, J.C., 1998. Seeing like a State: How Certain Schemes to Improve the Human Condition Have Failed. Yale University Press, New Haven.

Shipton, P., 1995. Luo entrustment: foreign finance and the soil of the spirits in Kenya. Africa 65, 165-196.

Stiglitz, J., 1998. Towards a New Paradigm for Development: Strategies, Policies and Processes. UN, Geneva.

Umans, L., Arce, A., 2014. Fixing rural development cooperation? Not in situations involving blurring and fluidity. J. Rural Stud. 34, 337-344.

van der Ploeg, J.D., 2003. The Virtual Farmer: Past, Present and Future of the Dutch Peasantry. Royal Van Gorcum, Assen.

van der Ploeg, J.D., 2010. The peasantries of the twenty-first century: the commoditisation debate revisited. J. Peasant Stud. 37, 1-30.

van Kessel, C., 1998. Adoption, Adaptation, Distancing and Alternative Networks. An Analysis of Farmers' Responses to a Hybrid Maize Technology Package in Yala Division, Western Kenya. Unpublished M.A. thesis. Dept. of Development studies. Nijmegen, Radboud University, Nijmegen.

Wanjala, B., 2016. Can the Big Push Approach End Rural Poverty in Africa? Insights from Sauri Millennium Village in Kenya. Unpublished Ph.D. thesis. Tilburg University. Center for Economic Research, Tilburg.

Wanjala, B., Muradian, R., 2013. Can big push interventions take small-scale farmers out of poverty? Insights from the Sauri Millennium Village in Kenya. World Dev. 45, $147-160$.

Wilson, J., 2013. Model villages in the neoliberal era: the Millennium Development Goals and the colonization of everyday life. J. Peasant Stud. 41, 107-125.

Wilson, J., 2014. Jeffrey Sachs: the Strange Case of Dr. Shock and Mr. Aid. Verso, London.

Wilson, J., 2015. Paradoxical utopia: the millennium villages project in theory and practice. J. Agrar. Change 41, 107-125.

Wilson, J., 2016. The village that turned to gold: a parable of philanthrocapitalism. Dev. Change 47, 3-28.

Woods, M., 2015. Territorialisation and the assemblage of rural place: examples from Canada and New Zealand. In: Dessein, J., Battaglini, E., Horlings, L. (Eds.), Cultural Sustainability and Regional Development: Theories and Practices of Territorialisation. Routledge, London, pp. 29-43.

Yuksel, N., 2013. Constructing a Green Revolution: a Socio-technical Analysis of Inputsupport Programmes for Smallholder Farmers in Western Kenya. Unpublished M.A. thesis. University of Sussex, Sussex. 